\title{
Increased Activity, Motivation and Learning Outcomes Mathematics with Learning Model Cooperative Type Numbered Head Together in Grade III Students
}

\author{
Samsul Adianto \\ Primary school teacher Education, Widya Gama Mahakam Samarinda University, Indonesia \\ samsul4adianto@gmail.com
}

\begin{abstract}
Keywords:

Activities,

Motivation,

Learning Outcomes,

Number Head Together.

The research seeks to examine how models of the cooperative learning of type Number Head Together are able to improve student activity, motivation and learning outcomes. The purpose of this study type is the research action Class (PTK), the data source in this research is all grade III students at SDN Sungai Kunjang. The data collection techniques are observations, tests, and documentation. The data analysis technique used is a descriptive quantitative analysis technique and qualitative analysis. The results of the study and discussion showed (1) cooperative learning Model type Numbered Heads Together (NHT) can increase the learning activity of class III elementary School of SD State 003 Samarinda. It is shot from the average cycle activity I reached 2.91 and increased by 3.16 in cycle II; (2) The Model of cooperative learning type Numbered Heads Together (NHT) can increase the motivation to learn to study students of grade III SD Negeri 003 Kunjang River. Increased motivational learning is gained from the observation results of each cycle, where cycle I reaches 3.3, and cycle II reaches 3.64 ; (3) The Model of cooperative learning type Numbered Heads Together (NHT) can improve student learning outcomes of Grade III Elementary School, 003 Sungai Kunjang. This is an image of the learning value of the cycle I reached at $83.33 \%$, and cycle II reaches $95.83 \%$.
\end{abstract}

$\begin{array}{ll}\text { Article History: } & \\ \text { Received: } 14-10-2018 & \text { (9) (O) } \\ \text { Revised : } 27-12-2018 & \text { This is an open access article under the CC-BY-SA license } \\ \text { Accepted: } 28-12-2018 & \text { Crossref } \\ \text { Online }: 30-12-2018 & \text { https://doi.org/10.31764/ijeca.v1i3.2123 }\end{array}$

\section{A. INTRODUCTION}

Through preliminary study at SDN 003 Sungai Kunjang The teacher of the class said that, low student learning outcomes in particular class III on mathematics subjects did not achieve the minimum submission criteria (KKM) set by the school of 65 . The lack of such learning outcomes is because most of the students are unhappy with the math lessons so they have difficulty understanding the material in mathematics as opposed to the material in other lessons. Cooperative learning is a learning model focused on the use of small groups of students to cooperate in maximizing learning conditions to achieve learning objectives (Isjoni, 2013). The research conducted by Slavin proves that the use of cooperative learning can improve students ' learning outcomes as well as improve the ability of social relations, foster a lack of attitude and increase confidence (Slavin, 2010). 
In cooperative learning are known to various types. One of them is cooperative learning type Numbered Head Together (NHT). NHT is a variation of the group discussion whose trademark is the teacher only appoint a student who represents the group without informing in advance who will represent the group. This can enhance individual responsibilities in group discussions, with the involvement of all members of the group of course will positively impact the students ' learning interests (Anita, 2004). Based on this background, researchers are interested in conducting research. To overcome this problem is to implement cooperative learning model type Numbered Head Together (NHT).

\section{B. METHODS}

The type of research used in this study is class action research (PTK). According to Hopkins (Al-Tabany, 2014) that class action research is a research that combines research procedures with substantive action, an action carried out in an Inkuri discipline, or a person's attempt to understand what is happening, while engaging in a process of repair and change.

Class action research consists of a series of four activities performed in a recurring cycle. The four main activities that exist on each cycle are (a) planning actions, (b) Implementation of action, (c) Observation (observation), and (d) reflection. (Widayati, 2014). Research Data is an increase in learning outcomes for mathematics on materials taught using cooperative models NHT (numbered head together) (Haniyah, 2014). The source of this assessment data is a grade III student of SDN 003 Sungai Kunjang consisting of 24 students, male students 12 people and female students 12 people.

Data collection techniques, conducted by: observation, tests. The data analysis used is qualitative data analysis and quantitative data analysis (Arikunto, 2010). Qualitative data analysis is an analysis that processes and analyzes the accumulated data of the process of observation of learning that apply the cooperative learning model of NHT type into a systematic, orderly and structured data and has meaning (Sugiyono, 2017). In this qualitative data analysis use one of the models of interactive analysis techniques. Interactive analysis consists of three components of activity that are interconnected with each other namely data reduction, data feed, and conclusion withdrawal (Sutopo, AH; Arief, 2010).

\section{RESULT AND DISCUSSION}

\section{Learning Activities}

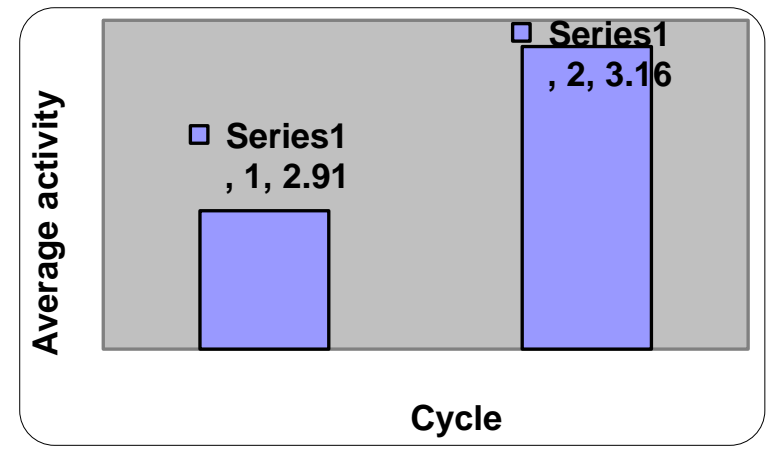

Figure 1. Learning Activities of State Elementary School 003 Kunjang River

Based on Figure 1 above, shows significant increase in student activity in both cycle 1 and cycle 2, where average student activity in Cycle 1 of 2.91 increased by 0.25 in cycle 2 or increased to 3.16. 


\section{Learning Motivation}

a. Cycle 1 . The average student learning motivation at 1 -Cycle 1 meeting is 2.71 which is quite categorized.

b. Cycle 2. To get an overview of student learning motivation in learning by using NHT learning models shows the average learning motivation of students in managing learning in Cycle 2 experienced an increase from cycle 1, where the average learning motivation for students in managing learning in Cycle 2 is 3.64 that is well-categorized.

\section{Student Learning Data}

a. Pre cycle

Preliminary Data before any action or commonly called a pre-cycle is known that from the 24 students who got a value of $>65$ as many as 9 students or $37.5 \%$ complete, while 15 students or $62.5 \%$ have not been completed. The average value on the pre cycle is 58.125 .

b. Cycle 1

After learning by using the model of cooperative learning type Numbered Head Together obtained the average value of students ' mathematical learning results increased from the value of 58.125 rose to 74.58 with a difference in the percentage of students ' learning from initial value to cycle I of $45.83 \%$.

Based on the results of a descriptive analysis of the student activity on Cycle 1, as Seen on (appendix 3 and 4), indicates that the average student activity in Cycle 1 is 2.91 in sufficient category (Zainal Aqib dan Ahmad Amrullah, 2018).

c. cycle 2

Based on the results of learning mathematics in Grade III elementary School 003 Kunjang River after being taught by implementing a cooperative learning model type Numbered Heads Together shows the improvement of both the initial test and the student learning outcomes at each cycle, where the average student learning outcomes at Cycle 1 is 74.58 and the average student learning results in the 2nd cycle of 95 . Based on the data, demonstrated significant increase in student learning outcomes both from the initial test and student learning outcomes at each cycle, where the average initial test of the student was 58.125 with a maximum value of 70 and a minimum value of 40 . While the average student learning results in Cycle 1 is 74.58 with a maximum value of 85 and a minimum value of 60. Then the average student learning results in Cycle 2 increased by 95 with a maximum value of 100 and a minimum value of 60 . Based on the increasing number of students that has been completed classively at every cycle, where in cycle 1 there are $83.33 \%$ of students who have been completed while in Cycle 2 there are $95.83 \%$ of students who have completed.

The results showed that mathematics learning through cooperative learning models of Numbered Heads Together can increase the average value of student learning outcomes to 95 and meet all the learning indicators well in the cycle 2, so researchers with observer decide to stop learning until cycle 2 .

Based on the results of a descriptive analysis of the student activity in Cycle 2 indicates a very significant increase in student activity from Cycle 1 , with the average student activity to cycle 1 is 2.91 with a category sufficiently increased in Cycle 2 to be 3.14 in good category.

Based on the results of a descriptive analysis of the increase in student outcomes from Cycle 1 to cycle 2, indicates the presence of a significant increase in learning outcomes from cycle 1 to cycle 2 that has increased. Increased student learning results were also seen in the preliminary test results, that based on the results of the analysis was obtained on average the student initial test result of 58.125 where the maximum student value of 70 and student minimum value of 40 and the number of students who had not reached the KKM amounted to 15 people and the number of students who had reached the KKM amounted to 9 persons. 
Vol. 1, No. 3, December 2018, pp. 35-38

\section{CONCLUSION AND SUGGESTIONS}

Based on the results of the analysis of several cycles and discussions, it can be concluded that: Model Cooperative Learning Type Numbered Heads Together can increase the learning activity of grade III students in SD Negeri 003 Sungai Kunjang. It is shot from the average cycle activity 1 reached 2.91 and increased by 3.16 in cycle 2 .

Model Cooperative Learning Type Numbered Heads Together can improve the learning motivation to learn students grade III Elementary School of State 003 Sungai Kunjang. Increased motivational learning is gained from the observation results of each cycle, where cycle 1 reaches 3.3, and cycle 2 reaches 3.64 .

Model Cooperative Learning Type Numbered Heads Together can improve student learning results of Grade III Elementary School 003 of Kunjang River. This is an image of the learning value of the cycle 1 reached at $83.33 \%$, and cycle 2 reaches $95.83 \%$.

After conducting the research and seeing the results, the researcher suggested as follows: 1) Teachers are expected to apply cooperative learning, especially in the cooperative learning of Numbered Head Together type in the learning process. 2) To further researchers are expected to conduct research on the implementation of other learning models that can arouse the activity, motivation and learning of students.

\section{REFERENCES}

Al-Tabany, T. I. B. (2014). Mendesain model pembelajaran inovatif, progresif, dan kontekstual. In Prenadamedia Group.

Anita, L. (2004). Cooperative Learning: Mempraktikkan Cooperative Learning di Ruang-Ruang Kelas. Jakarta: PT. Gransindo.

Arikunto. (2010). Metodelogi Penelitian. Pendekatan Penelitian, 61-84.

Haniyah, L. (2014). Model Pembelajaran Kooperatif Tipe NHT (Numbered Head Together) Disertai Metode Eksperimen Pada Pembelajaran IPA Fisika SMP. Jurnal Pembelajaran Fisika, 2-10.

Isjoni. (2013). Pembelajaran Kooperatif. Pustaka Pelajar.

Slavin, R. E. (2010). Cooperative learning. In International Encyclopedia of Education (pp. 177-183). https://doi.org/10.1016/B978-0-08-044894-7.00494-2

Sugiyono. (2017). Sugiyono, Metode Penelitian. Penelitian, 34-45. https://doi.org/10.1021/ol7029646

Sutopo, AH; Arief, A. (2010). Terampil Mengolah Data KUalitatif dengan NVIVO. In Penerbit Prenada Media Group.

Widayati, A. (2014). Penelitian Tindakan Kelas. Jurnal Pendidikan Akuntansi Indonesia, 6(1). https://doi.org/10.21831/jpai.v6i1.1793

Zainal Aqib dan Ahmad Amrullah. (2018). Penelitian Tindakan Kelas Teori Dan Aplikasi (F. S. Suyantoro (ed.)). Penerbit ANDI. 